\title{
Rejestracja jednostki leksykalnej mem i memetyka w słowniku języka angielskiego i języka polskiego w kontekście implikacji filozoficznych
}

„Teksty z Ulicy. Zeszyt memetyczny” 2019, nr 20

Https://doi.org/10.31261/tzu.2019.20.08

\section{Streszczenie}

Artykuł ma charakter komparatywny odnośnie do rejestracji w języku angielskim jak i języku polskim jednostek leksykalnych mem i memetyka. W części pierwszej została przedstawiona etymologia wspomnianych jednostek w perspektywie historycznej. W części drugiej została zwrócona uwaga na filozoficzne konsekwencje rozumienia pojęcia teoria przez Richarda Dawkinsa jako ważne narzędzie formowania teorii memetycznej.

\section{Słowa klucze:}

ewolucja kultury, terminy specjalistyczne, memetyka, filozofia kultury, Richard Dawkins

\section{Recording of the lexical unit of meme and memetics in Polish and English dictionaries in its philosophical implications}

\section{Summary}

The article has a comparative character regarding the enrollment in English and Polish lexical unit meme and memetics. The first part of the paper is devoted, indeed, to the English as well as Polish word-formation etymology of meme and memetics lexical units. In part two, special attention is paid to the philosophical values of term theory used by Richard Dawkins as a vital instrument of memetics theory formation.

Keywords:

cultural evolution, functional terms, memetics, culture philosophy, Richard Dawkins

\section{Wprowadzenie}

W literaturze przedmiotu rozpowszechnił się sposób omawiania zagadnień odnoszących się do memetyki poprzez odwołanie się głównie do pracy Richarda Dawkinsa The Selfish Gene (1976). Hipotezy przedstawione w tej książce są omawiane (rekapitulowane) i interpretowane w aspekcie ewolucji kulturowej (ang. cultural evolutionary theory), która jest traktowana jako analogon ewolucji biologicznej 
(darwinowskiej). W propozycji Dawkinsa podstawową (bazową) jednostka naturalnej selekcji ${ }^{1}$ jest byt, który został nazwany przez tego badacza memem². Mimo, że w większości prac poruszających problemy związane z ewolucją kulturowa jak i kulturą cyfrową (cyberhumanistyka, humanistyka cyfrowa, itd.) prace takich badaczy jak Dawkins, Susan Blackmore czy Daniel Dennett stanowią teoretyczny fundament, to hipotezy badawcze jak i hipotezy pomocnicze memetyki sa słabo znane ${ }^{3}$. Z drugiej zaś strony, w literaturze przedmiotu można wskazać liczne prace, w których badacze poddają rozważaniom własności memu, modyfikując definicję tego pojęcia - termin. Badacze podejmujący trud rozważań teoriopoznawczych albo odwołują się bezpośrednio do źródeł, albo do definicji słownikowych bądź encyklopedycznych, albo do zasłyszeń, które przyczyniają się do mitologizowania pojęcia mem. Memetyka trwale wpisuje się w historię idei XX w. (być może i XXI), dlatego koniecznym jest rzetelne opracowanie etymologii jednostki leksykalnej mem i memetyka w lekcji angielskiej i polskiej. Niniejszy artykuł ową lukę uzupełnia.

\section{Implikacje filozoficzne}

W literaturze przedmiotu znane są i inne etymologie nazwy meme, które należy nazwać alternatywnymi, ponieważ mimo jasno opisanego przez Dawkinsa zamysłu, badacze skłonni są do konstruowania własnych wersji, choć są one nieuzasadnione. Zazwyczaj sprowadza się w tym wypadku dyskusje do inspiracji merytorycznych bądź filozoficznych Dawkinsa. Będą to jednak daleko idące spekulacje sugerujące nawet dokonanie przez Dawkinsa tzw. miękkiego plagiatu, który jest materialnie niedowodliwy. Znane są poszukiwania semantycznych i graficznych podobieństw do jednostki meme, co rzekomo ów zarzut potwierdza. Przykładem takich spekulacji jest list Johna Laurenta opublikowany w roku 1999 na łamach "Journal of Memetics" pt. A Note on the Origin of Memes/Mnemes ${ }^{4}$, w którym autor zwraca uwagę na inne pochodzenie jednostki meme, niż to, które sugeruje Dawkins ${ }^{5}$. Zarzuty Laurenta nie zostały poparte dowodami. Można

1 K. Distin, The Selfish Meme. A Critical Reassessment, Cambridge 2005, s. 6.

2 Zob. J. Gunders, D. Brown, The Complete Idiot's Guide to Memes, New York 2010.

${ }^{3}$ W literaturze przedmiotu można spotkać prace naukowe, w których przy omawianiu problemów związanych z memem internetowym nie zostaje dostatecznie rozpoznana sytuacja historyczno-problemowa, co wiedzie badaczy do zaskakujących wniosków, np. odnośnie do okoliczności powstania pierwszego memu internetowego. Więcej na ten temat w osobnym artykule.

4 Źródło: http://cfpm.org/jom-emit/1999/vol3/laurent_j.html [dostęp: 10.05.2015].

${ }_{5}$ „Badacz ten odnosi się do lekcji [mneme], która pochodzi z greckiego [ $\left.\mu 1 \mu \varepsilon i ̈ \sigma \theta \alpha 1\right]-$

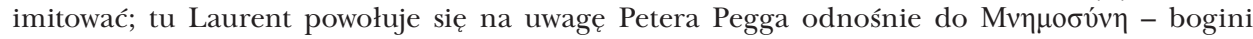
pamięci; ponadto Laurent stawia tezę, że Dawkins prawdopodobnie zapoznał się z pracą Maurice’a

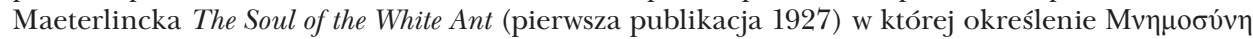
się pojawia; Laurent argumentuje, że w Selfish Gene jak i w The Blind Watchmaker Dawkins dużo miejsca poświęca termitom, cytuje także różne poświęcone im prace, ale nie wspomina pracy Maeterlincka”. R. Boroch, Siedem bram memetyki (SBM2). Recepcja Samolubnego genu Richarda Dawkinsa w angielskiej literaturze przedmiotu w latach 1976-1989. Warszawa 2016, s. 80-82. 
zastosować kryterium subiektywne polegające na założeniu, że: „Racja X-a jest fałszywa, ponieważ postawa X-a względem religii jest niewłaściwa”. Należy jednak zadać sobie odważne pytanie odnośnie do samego zjawiska, które mogło zostać dostrzeżone przez różnych badaczy w różnym czasie i adekwatnie do stanu dostępnej owym badaczom wiedzy nazwane. W praktyce widoczne jest odrzucenie wszystkich innych argumentacji z wyjątkiem pierwszej. Argumentacja Laurenta może wydawać się przekonującą. Badacz ten stwierdza: „[...] an engram is a memory trace; specif.: a protoplasmic change in neural tissue hypothesized to account for persistence of memory"6.

Określenie engram (engrammata) znaczy tyle, co ślad w pamięci; w znaczeniu szczególnym: „protoplazmatyczna zmiana w tkance nerwowej, teoretycznie odpowiada za podtrzymanie/utrzymanie pamięci"7. Zwróćmy uwagę, że Dawkins w roku 1971 publikuje artykuł pt. Selective Neurone Death as a Possible Memory Mechanism ${ }^{8}$. W artykule tym pisze:

I propose that selective neurone death may be a mechanism of information storage in the brain. The parallel between learning and evolution would thus be even closer than has hitherto been suggested. In both cases non-random death would be the mechanism of increase in complexity and adaptiveness ${ }^{9}$.

W kolejnym akapicie dodaje:

I shall not suggest details, or give evidence for this idea, but simply point out that it is a plausible possibility which deserves to be considered alongside other vague theories with no supporting evidence ${ }^{10}$.

William H. Calvin w artykule The Six Essentials? Minimum Requirements for the Darwinian Bootstrapping of Quality ${ }^{11}$, opublikowanym przed artykułem Laurenta, bo w roku 1997, zwraca uwagę, że Dawkins w wyżej cytowanej pracy posługuje się określeniem selective neurone death, co należy rozumieć albo jako „selektywna śmierć neuronu” albo „śmierć selektywnego neuronu” - Dawkins przez określenie selective neurone death rozumie potencjalną możliwość przechowywania w mózgu ludzkim informacji jako wyniku konkretnego procesu, który to proces owo przechowywanie/składowanie/magazynowanie umożliwia (ang. information storage) - czyli engram Laurenta. Zastanówmy się, czy zamysł o nazwie selective neurone death może być uznany za preteoretyczny zamysł

${ }^{6}$ Za R. Boroch, Siedem bram memetyki..., s. 82.

7 E.C. Withmore, The Analogy of the Record, "The Journal of Philosophy” 1940, vol. 37, no. 26 (Dec. 19), 711-719; za: R. Boroch, Siedem bram memetyki..., s. 82.

${ }^{8}$ R. Dawkins, Selective Neurone Death as a Possible Memory Mechanism, „Nature” 1971, vol. 229, No. 5280, 118-119.

9 Tamże, s. 118.

10 Tamże.

11 W. H. Calvin, The Six Essentials? Minimum Requirements for the Darwinian Bootstrapping of Quality, "Journal of Memetics" 1997, No. 7, źródło: http://cogprints.org/3217/1/1997JMemetics. htm [dostęp: 10.10.2019]. 
memu? Ów preteoretyczny zamysł poszukiwania jednostki bazowej Dawkins przedstawia w roku 1977 podczas odczytu wygłoszonym na 15. Międzynarodowym Kongresie Etologicznym w panelu socjobiologicznym (ang. 15th International Ethological Conference, Bielefeld 1977) - zapis tego wystapienia został opublikowany w roku 1978 pod tytułem Replicator Selection and the Extended Phenotype ${ }^{12}$. Innym problemem, który przy tej okazji mimowolnie się ujawnia, to problem filozofii kultury jako systemu zaproponowanego przez Dawkinsa, systemu, którego hipotezy są rozproszone w wielu pracach autorstwa tego badacza. Czy można podjać próbę scalenia tych hipotez filozoficznych? Wielu badaczy na ten właśnie problem zwraca uwagę. Na przykład, Derek Gatheres w artykule Macromemetics: Towards a Framework for the Re-unification of Philosophy z roku $1997^{13}$ stwierdza, że mem bezspornie koresponduje z popperowskim światem trzecim, argumentując:

It is clear from this that Popper and Dawkins have similar concepts in mind. Although Popper's first three specific examples could be grouped under the heading of Dawkins' third example ie. 'ideas', his inclusion of printed artifacts such as the contents of libraries demonstrates that Popper, like Dawkins, also wishes to include the physical manifestations of transmitted information in his definition. In other words, both authors fail to make a clear distinction between what Speelterms the memotype and the phenotype. Popper also intends that World 3 should include all objective thought contents both past and present. Concepts evolve in World 3 just as genes evolve in World 1, but World 3 does not itself evolve ${ }^{14}$.

W polskim piśmiennictwie powyższy problem akcentuje Dobrosława Wężowicz-Ziółkowska w książce Moc narrativum (rok wydania: 2008) ${ }^{15}$. Ważnym problemem korespondującym z propozycją Poppera jest hipoteza odnosząca się do konieczności przedstawienia fizycznej manifestacji transmitowanej informacji (ang. phisical manifestation of transmitted information), na przykład w postaci drukowanych artefaktów - Popper wskazuje tu na zawartość bibliotek, Dawkins zaś na same książki, itd. Wydaje się zatem uzasadnione analitycznie scalenie problemów odnoszących się do pozagenetycznej informacji kulturowej w kontekście transmisji:

12 R. Dawkins, Replicator selection and the extended phenotype, "Zeitschrift fur Tierpsychologie" 1978, 47 (1), pp. 61-76.

13 D. Gatheres, Macromemetics: Towards a Framework for the Re-unification of Philosophy, "Journal of Memetics" 1997, No. 1, źródło: http://cfpm.org/jom-emit/1997/vol1/gatherer_ dg.html [dostęp: 10.10.2019]. Gatherer wskazuje na Popperowskie wzorce w myśli Dawkinsa także w artykule: D. Gatherer, Finding a Niche for Memetics in the $21^{s t}$ Century, "Journal of Memetics" 2005, No. 6.

14 D. Gatheres, Macromemetics...

15 D. Wężowicz-Ziółkowska, Moc narrativum. Idee biologii we wspótczesnym dyskursie humanistycznym, Katowice 2008. Warto odnotować, że w 2012 r. Andrzej Stępnik publikuje artykuł Model zmian kulturowych: między ewolucja a rewolucja kulturowa, w którym dokonuje innego ujęcia problemu, proponując adaptację memetyczną programu badawczego Imre Lakatosa (ang. Lakatos scientific research). Propozycja ta koresponduje z Łotmanowską antynomią semiotyki kultury: jądro - peryferie. Zob. A. Stępnik, Model zmian kulturowych: między ewolucja a rewolucja kulturowa, „Teksty z Ulicy. Zeszyt memetyczny” 2012, nr 14, s. 81-92. 
a) sygnału; b) informacji; a także c) ilości informacji w sygnale; d) istoty transmisji; czy e) przekazu ${ }^{16}$ itd. ${ }^{17}$.

Dawkins w książce The Greatest Show on Earth. The Evidence for Evolution z roku $2009^{18}$ proponuje rozróżnienie znaczeń teoria (cytat 1) i hipoteza (cytat 2) ${ }^{19}$.

[1] Theory, Sense 1: A scheme or system of ideas or statements held as an explanation or account of a group of facts or phenomena; a hypothesis that has been confirmed or established by observation or experiment, and is propounded or accepted as accounting for the known facts; a statement of what are held to be the general laws, principles, or causes of something known or observed.

[2] Theory, Sense 2: A hypothesis proposed as an explanation; hence, a mere hypothesis, speculation, conjecture; an idea or set of ideas about something; an individual view or notion ${ }^{20}$.

Rozumienie teorii w sensie pierwszym jest zdaniem Dawkinsa nieporównywalnie bardziej złożone. Optymalne byłoby posługiwanie się jednym terminem „teoria”, jednakże jest to mylące, ponieważ „teorią” określa się i to, co jest całościowym systemem poznawczym, w którym istnieją fakty, i to, co jest hipotetyczne, czyli niepotwierdzone. Zdrowy rozsądek i obserwacje pozwalaja jednak na sformułowanie hipotezy, lecz nie na jej potwierdzenie. Sąd potwierdzony jest sądem prawdziwym i staje się twierdzeniem, co w języku angielskim w matematyce nazywa się „theorem” (tłumacz polskiego przekładu cytowanej książki Dawkinsa wybrał lekcję [teoremat] ${ }^{21}$ ), gdzie theorem znaczy tyle, co twierdzenie. Posłużmy się tu nomenklaturą angielską w celu klarownego przedstawienia różnic. Dawkins proponuje inny termin - „theorum”. Bazą słowotwórczą jednostki leksykalnej theorum jest zapożyczona z matematyki jednostka w lekcji [theorem]. Dawkins dokonuje tu jednak celowej literówki - zamiast lekcji [theorem] proponuje

${ }^{16}$ Konieczna jest tu znajomość prac: Semiotics. An Introduction Anthology, ed. R.E. Innis, Bloomington 1985; T. Sebeok Global Semiotics, Bloomington 2001; J.J. Liszka A General Introduction to the Semiotic of Charles Sanders Peirce, Bloomington 1996; G. Deledalle, Charles S. Peirce's Philosophy of Signs. Essays in Comparative Semiotics, Bloomington 2001.Więcej na temat prac Peirce'a zobacz: http://www.iupui.edu/ peirce/index.htm [dostęp z dnia 5.11.2019]. Pełne wydanie prac Peirce'a: Ch.S. Peirce, Collected papers, vol. 1-6 ed. by Ch. Hartshorne and P. Weiss; vol. 7-8 ed. by A.W. Burks. Cambridge 1958-1966. Nowe wydanie: Writings of Charles S. Peirce: A Chronological Edition, Bloomington 2010.

17 Inne inspiracje filozoficzne Dawkinsa, o których on sam pisze we wstępie do The Selfish Gene, to prace: Karla Poppera The Rationality of Scientific Revolution (1974); Luigi Luca CavalliSforzy Similarities and Dissimilarities of Sociocultural and Biological Evolution (1971); F. Teda Cloaka Jr. Is Cultural Ethology Possible? (1975) oraz Johna Michaela Cullena Some Principles of Animal Communication (1972). Na szczególną uwagę w kontekście omawianej tu problematyki zasługuja prace F. Ted Cloaka Jr. Perceptual Control Theory, źródło: http://www.tedcloak.com [dostęp: 17.07.2015].

18 R. Dawkins, The Greatest Show on Earth. The Evidence for Evolution, New York 2009.

19 Rozróżnienie to funkcjonuje w polskiej tradycji naukowej od dawna.

20 R. Dawkins, The Greatest Show on Earth..., kindle location 365.

${ }_{21}$ Zob. R. Dawkins, Najwspanialsze widowisko świata. Świadectwa ewolucji, przeł. P.J. Szwajcer, Warszawa 2010, s. 25. 
właśnie lekcję [theorum], co uwalnia jednostkę leksykalną w lekcji [theorem] od znanej czytelnikowi definicji; czytelnik musi zaakceptować, jak zaznacza Dawkins, jego definicję terminu theorum ${ }^{22}$. Theorum w propozycji Dawkinsa nie może być udowodniony tak, jak dowodzi się theorem w matematyce; Dawkins rozumie theorum jako założenie pomocne do udowodnienia czegoś (czyli postulat):

A scientific theorum has not been - cannot be - proved in the way a mathematical theorem is proved. But common sense treats it as a fact in the same sense as the "theory" that the Earth is round and not flat is a fact, and the theory that green plants obtain energy from the sun is a fact ${ }^{23}$.

Zdaniem Dawkinsa theorum, podobnie jak fakt, nie wymagają dowodzenia opartego na aksjomatach, dlatego zarówno fakt, jak i theorum mogą być fałszywe, ponieważ to, co obserwowane może wydać się obserwującym zupełnie inne, niż jest w rzeczywistości; podobnie jest z zeznaniem lub świadectwem czegoś. Dawkins powołuje się w tym miejscu na eksperyment Daniela J. Simonsa, znany w literaturze przedmiotu jako Invisible Gorilla ${ }^{24}$. Autor Samolubnego genu kwestionuje na tej podstawie definicję faktu, stwierdzając, że jego rozumienie, jako tego, co aktualnie postrzegamy, jest mylące. Konsekwencje tego stanowiska są następujące: biolodzy ewolucyjni, twierdzi Dawkins, dokonują rozróżnienia między faktem ewolucji a teorią opisującą czynniki, które ewolucję w jakiś sposób warunkują. W zaproponowanej przez Dawkinsa terminologii ewolucja to theorum, co chyba należy rozumieć tak, że teoria jest interpretacją faktu. Zauważmy, że

${ }^{22}$ R. Dawkins, The Greatest Show on Earth..., s. kindle location 395.

23 Tamże. W dalszej części swojej pracy Dawkins odwołuje się do słownikowej definicji „faktu”, opierając się na oksfordzkim słowniku języka angielskiego: Fact: Something that has really occurred or is actually the case; something certainly known to be of this character; hence, a particular truth known by actual observation or authentic testimony, as opposed to what is merely inferred, or to a conjecture or fiction; a datum of experience, as distinguished from the conclusions that may be based upon it. R. Dawkins, The Greatest Show on Earth..., Tamże, s. kindle location 400. Polski przekład: „Fakt - coś, co się naprawdę zdarzyło albo jest tak rzeczywiście; coś, co na pewno jest znane, że jest o takim to a takim charakterze; szczególny sąd, prawda znana z konkretnej obserwacji albo świadectwo czegoś, w przeciwieństwie do tego, co jest wywnioskowane albo przypuszczalne, fikcyjne (na podstawie pojęć lub terminów - RB); fakt doświadczenia odróżnia się od wniosku, który się na takim doświadczeniu opiera.” (przeł. RB).

${ }^{24}$ Eksperyment Invisible Gorilla został przeprowadzony przez Christophera F. Chabrisa i Daniela J. Simonsa (zob. The Ch. Chabris, D. Simons, Invisible Gorilla and Other Ways Our Intuition Deceives Us, New York, 2010. Film dokumentujący eksperyment dostępny jest pod adresem: www.theinvisiblegorilla.com/gorilla_experiment.html [dostęp: 7.06.2012]. Przebieg eksperymentu był następujący: sześcioro uczestników eksperymentu Invisible Gorilla zostało ustawionych w kole; poproszono ich o podawanie sobie kozłem lub rzutem nad głową dwóch piłek koszykowych, przy jednoczesnej zamianie miejsca. Uczestnicy byli filmowani przez 25 sekund; po tym ćwiczeniu uczestnicy zostali poproszeni o podanie, ile razy każdy z nich rzucił/ upuścił/odbił piłkę (za: Dawkins 2009). Następnie uczestnicy zostali zapytani, czy któryś z nich zauważył człowieka przebranego za goryla - to była właściwa część eksperymentu, mająca na celu zbadanie zdolności obserwacji. Uczestniczący w eksperymencie nie byli w stanie jednoznacznie potwierdzić, czy faktycznie pojawił się człowiek w przebraniu goryla. Uczestnikom pokazano film, w którym rzeczywiście pojawiał się człowiek w przebraniu goryla (tamże). 
paleontologia dostarczyła wielu empirycznych dowodów potwierdzających fakt ewolucji. Spory w ramach ewolucji dotyczą teorii, czyli interpretacji faktów. Czy to samo można powiedzieć o memie i memetyce? Czy mem jest theorum, zaś transmisja informacji w ramach kultury faktem? Innymi słowy: czy w memetyce można mówić o „theorum” w rozumieniu Dawkinsa?

\section{Rejestracja jednostki leksykalnej meme w języku angielskim}

Pierwsza rejestracja w słowniku języka angielskiego jednostki leksykalnej w lekcji [meme] następuje w roku $1976 \mathrm{w}$ pracy Dawkinsa The Selfish Gene; także w roku 1976 jednostka leksykalna meme jest wymieniona w „New Scientist” - 9 grudnia $1976^{25}$. Dawkins proponuje poszukiwanie nowej nazwy nawiązującej w swojej propozycji do bazy słowotwórczej jednostki leksykalnej memory - pamięć. Badacz ten uznał, że adekwatną jednostką leksykalną byłaby tu jednostka w lekcji [mimeme $]^{26}$, którą zredukuje do formy jednosylabowej na wzór jednostki gene, która była już utrwalonym terminem biologicznym. Otrzymał w ten sposób jednostkę w lekcji [meme], która semantycznie może być kojarzona ze słowem memory oraz z francuskim słowem même, co znaczy tyle, co: ten sam/taki sam/taka sama, jeżeli jednostkę même potraktujemy jako zaimek.

\subsection{Etymologia formalna}

Dawkins uzasadniał, że w celu jasnego wytłumaczenia rozumienia przez niego procesów transmisji kulturowej (ang. cultural transmission) i naśladowania (ang. imitation) potrzebuje neologizmu, który nie byłby związany z utrwalonym powszechnie znaczeniem. Wymusiłoby to, jego zdaniem, uznanie takiego to a takiego znaczenia, które on obmyślił. Metodę stworzenia neologizmu w lekcji [meme] badacz tłumaczył w sposób następujący: potrzebna jest jednostka leksykalna, która budową morfologiczną będzie nawiązywała do terminologii w paradygmacie genetycznym, ponieważ językiem tego paradygmatu Dawkins objaśniał wymienione wyżej procesy zachodzące w kulturze, takie jak rozpowszechnianie się pomysłów, sloganów, melodii, mód, itd. Dlatego neologizm w planie graficznym, fonetycznym oraz semantycznym powinien odnosić się do: a) jednostki leksykalnej [gene]; b) jednostki leksykalnej [mimeme] od greckiego $[\mu i ́ \mu \eta \mu \alpha]$, co znaczy tyle, co „ten, który jest naśladowany”, lub „coś, co naślado-

${ }^{25}$ Kontekst: „A rational person who hasn't acquired any variety of the God meme described by Richard Dawkins”; za: OED, źródło: http://www.oed.com/view/Entry/239909?r edirectedFrom=meme\#eid [dostęp: 5.08.2015].

${ }^{26}$ We need a name for the new replicator, a noun which conveys the idea of a unit of cultural transmission, or a unit of imitation. "Mimeme" comes from a suitable Greek root, but I want a monosyllable that sounds a bit like "gene". I hope my classicist friends will forgive me if I abbreviate mimeme to meme. If it is any consolation, it could alternatively be thought of as being related to 'memory', or to the French word même. It should be pronounced to rhyme with “cream”. R. Dawkins, The Selfish Gene, Oxford 1976, s. 206. 
wało”, „coś, co jest skopiowane”; oraz c) francuskiej jednostki leksykalnej [même], co znaczy tyle, co „to samo” lub „podobne”. Innymi słowy, zdaniem Dawkinsa, potrzebny był neologizm jednosylabowy możliwy do użycia jako rzeczownik o zbliżonej wymowie do jednostki leksykalnej [gene], który by także nawiązywał

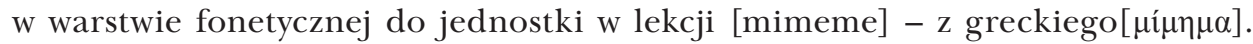
Dawkins zaproponował lekcję [meme] (fonetycznie $/-m i: m /)^{27}$, jako nazwę odnoszącą się do: a) przedmiotów albo obiektów rozpowszechnianych; oraz b) procesów je rozpowszechniających.

Przyjrzyjmy się oryginalnemu fragmentowi The Selfish Gene, wyd. z roku 1976, w którym to Dawkins swój zamysł tłumaczy:

We need a name for the new replicator, a noun which conveys the idea of a unit of cultural transmission, or a unit of imitation. „Mimeme” comes from a suitable Greek root, but I want a monosyllable that sounds a bit like ,gene”. I hope my classicist friends will forgive me if I abbreviate „mimeme” to "meme”. If it is any consolation, it could alternatively be thought of as being related to „memory”, or to the French word „meme”. It should be pronounced to rhyme with „,cream”. Examples of memes are tunes, ideas, catch-phrases, clothes fashions, ways of making pots or of building arches ${ }^{28}$.

Jednostka leksykalna w lekcji [mimeme] (fonetycznie /mi:mem/) w języku angielskim czy starogreckim jest semantycznym nonsensem. Dawkins wykorzystuje grecką bazę słowotwórczą $\mu \mu$-, od której mogą być utworzone takie jednostki

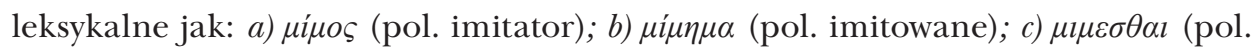
naśladowane).

\subsection{Etymologie alternatywne - wybrane przykłady}

Jedną z najciekawszych alternatywnych propozycji jest ujęcie Marion Blute zaprezentowane w artykule Memetics and Ewolutionary Social Sciense ${ }^{29}$, która stwierdza, że na budowę jednostki leksykalnej meme składa się przedrostek „m” - od jednostki memory (pamięć) oraz bazy słowotwórczej „eme” (ang. gene) ${ }^{30}$.

Inną etymologię rejestruje słownik Merriam-Webster Dictionary ${ }^{31}$ : aliteracja

${ }^{27} \mathrm{~W}$ amerykańskim zapisie fonetycznym /mēm/, co wymawia się jako / $\mathrm{mi}: \mathrm{m} /$, zob.: http:// www.merriam-webster.com/dictionary/meme [dostęp: 5.08.2015].

28 R. Dawkins, The Selfish Gene..., p. 206.

${ }_{29}$ M. Blute, Memetics and evolutionary social science, „Journal of Memetics - Evolutionary Models of Information Transmission” 2005, vol. 9, źródło: http://cfpm.org/jomemit/2005/ vol9/blute_m.html1 [dostęp: 07.11.2019].

30 "Memetics is the scientific study of memes. The term "meme" was coined by Richard Dawkins (1976), suggestive of " $\mathrm{m}$ " for memory or imitation and "eme" for gene, for the basic unit of hereditary information or replication involved in cultural as opposed to biological evolution.”, M. Blute, Memetics and evolutionary social science, „Journal of Memetics - Evolutionary Models of Information Transmission” 2005, vol. 9, źródło: http://cfpm.org/jomemit/2005/ vol9/blute_m.html1 [dostęp: 07.11.2019].

31 Merriam-Webster Dictionary, źródło: https://www.merriam-webster.com/ [dostęp: 12.11.2019]. 
mimeme od mim- (jako mimesis) oraz -eme. Jednostkę leksykalną meme rejestruje także słownik Oxford English Dictionary ${ }^{22}$, podając etymologię grecką $\mu i ́ \mu \eta \mu \alpha$ - to, co jest imitowane; oraz $\mu \iota \varepsilon \varepsilon \sigma \theta \alpha l-$ to, co jest naśladowane ${ }^{33}$.

\subsection{Podsumowanie}

W roku 1988 jednostka leksykalna meme została umieszczona na liście słów przeznaczonych do formalnego opracowania słownikowego w kolejnych edycjach Oxford English Dictionary. Historyczne konteksty rejestracji jednostki meme sprowadzają się do siatki pojęć: „Społeczeństwo $\rightarrow$ społeczność/zbiorowość/ wspólnota $\rightarrow$ społeczeństwo w relacji do zwyczajów/obyczajów, wartości, przekonań $\rightarrow$ kulturowy element przekazywany za pomocą niegenetycznego środka" 34 .

\section{Rejestracja jednostki leksykalnej memetics w języku angielskim}

Douglas Hofstadter w pracy Metamagical Themas: Questing For the Essence of Mind and Pattern opublikowanej po raz pierwszy w roku 1985 pisze, że nazwę w lekcji [memetics $]^{35}$ na określenie dziedziny studiów badających memy i ich związków z ludźmi zaproponowała Arel Lucas"36 ("Arel Lucas suggested that the discipline that studies memes and their connections to humans and other potential carriers of them be known as memetics, by analogy with "genetics «") ${ }^{37}$.

Pojawia się w tym wypadku kilka wątpliwości. John Gunders i Damon Brown podają, że nazwa memetics była sugestią czytelników, którą Hofstadter zaakceptowa $^{38}$. Ponadto jednostka leksykalna w lekcji [memetics] nie jest rejestrowana w słowniku języka angielskiego; dodam, że Oxford English Dictionary rejestruje kontekst, w którym pojawia się jednostka w lekcji [memetic] (nie w lekcji [memetics]) już w roku 1977, co poddaje w wątpliwość powyższe sugestie ${ }^{39}$.

${ }^{32}$ Oxford English Dictionary, źródło: https://www.oed.com/ [dostęp: 12.11.2019].

${ }_{33}$ Dla porównania, Stownik grecko-polski Abramowiczówny definiuje mimema następująco: $\mu i ́ \mu \eta \mu \alpha$ (mimema) - I 1. artystyczne odtworzenie, 2. naśladownictwo, podobizna, obraz. II przedmiot naśladowania. Zwróćmy jednak uwagę, że powyższe problemy Dawkins rozstrzyga jednoznacznie wskazując na kierunek interpretacyjny: nie naśladowanie, lecz imitowanie: "Just as genes propagate themselves in the gene pool by leaping from body to body via sperms or eggs, so memes propagate themselves in the meme pool by leaping from brain to brain via a process which, in the broad sense, can be called imitation" (R. Dawkins The Selfish Gene, s. 206). Przekład: Tak jak geny mnożą się w puli genów poprzez przeskakiwanie z ciała do ciała przez spermę albo jaja, tak memy mnożą się w puli memów poprzez przeskakiwanie z mózgu do mózgu w procesie, który w najszerszym znaczeniu, może być nazwany imitowaniem. [przekł. mój - R.B.].

34 "society $>$ the community $>$ society in relation to customs, values, or beliefs $>$ [noun] $>$ cultural element passed on by non-genetic means (1)". Źródło: http://www.oed.com/view/th/ class/154889 [dostęp: 11.05.2015].

${ }^{35}$ Spotykana jest także lekcja [memetic].

${ }^{36}$ Inni badacze John Gunders i Damon Brown podają, że nazwa memetics była sugestia czytelników, którą Hofstadter zaakceptował (J. Gunders, D. Brown, The Complete Idiot's Guide...).

${ }_{37}$ D. Hofstadter, Metamagical Themas: Questing For the Essence of Mind and Pattern, Penguin Books Ltd. 1993, s. 65.

${ }^{38} \mathrm{~J}$. Gunders, D. Brown, The Complete Idiot's Guide...

${ }_{39}$ Źródło: http://www.oed.com/view/Entry/251726?rskey=sU7Ur7\&result=5\# [dostęp: 29.01.2015]. 
Jednostka leksykalna w lekcji [memetics] nie jest formalnie rejestrowana przez Oxford English Dictionary, rejestruje ją na przykład słownik dictionary. com $^{40}$.

\section{Rejestracja jednostki mem i memetyka w języku polskim}

Jednostkę leksykalną w lekcji [mem] do języka polskiego wprowadza Antoni Hoffman $^{41}$, tłumacz książki Dawkinsa The Blind Watchmaker (1985) w roku 1994 (polski przekład: Ślepy zegarmistrz). Hoffman jest pierwszym polskim tłumaczem książkowych prac Dawkinsa, który wprowadza do języka polskiego jednostkę mem, jako odpowiednik angielskiej jednostki meme, a także jednostkę leksykalną „ewolucja memetyczna” jako odpowiednik angielskiej jednostki memic evolution ${ }^{42}$. Dokonując adaptacji, tłumacz dokonał skrótu z lekcji angielskiej [meme] do lekcji [mem]. Powstały w ten sposób neologizm przypomina graficznie pierwowzór. Zasadnicze różnice dotyczą realizacji fonetycznej: a) wymowa angielska $/-m i: m /$; b) wymowa polska /mem/. Zwróćmy uwagę, że polska jednostka leksykalna mem nie jest uzualnie związana ze znaczeniami: „naśladowanie” czy „imitowanie” sensowniejsze wydawałoby się wybranie lekcji [mim]. Szerszy kontekst przekładu Hoffmana przedstawia tabela 1 .

Wersja Hoffmana - mem - została użyta nie tylko w przekładach prac Dawkinsa; na przykład Piotr Turski posługuje się lekcją [mem] w przekładzie książki Richarda Brodiego Virus of the Mind: The New Science of the Meme (polski przekład 1997), zaś Mariusz Biedrzycki w autorskiej pracy Genetyka kultury ${ }^{43}$.

${ }^{40}$ Memetics, hasło w: The Free On-line Dictionary of Computing. Denis Howe. 13 May. 2015. Dictionary.com, http://dictionary.reference.com/browse/memetics [dostęp: 5.08.2015].

41 Antoni Hoffman (1950-1992) — paleontolog ewolucyjny (ang. evolutionary paleobiologist), autor m.in.: Wokót ewolucji, Warszawa 1983, Arguments on Evolution. A Paleontologist's Perspective, New York 1989; pełna bibliografia prac Hoffmana: http://www.app.pan.pl/archive/ published/app38/app38-123.pdf \{dostęp: 1.07.2015].

${ }^{42} \mathrm{~W}$ tym miejscu chciałbym zwrócić uwagę na dwie kwestie. Pierwszą jest niefortunny przekład frazy w lekcji [they are (memes) patterns of information] jako [są (memy) zbiorami informacji]; zastrzeżenia budzi określenie w lekcji [pattern], które znaczy tyle co wzór, a nie jak proponuje Hoffman zbiór; kwestia druga to określenie w lekcji [memic evolution], które Hoffman tłumaczy jako [ewolucja memetyczna]. W brytyjsko-amerykańskiej literaturze przedmiotu rozpowszechnione jest określenie w lekcji [memetic evolution], w literaturze polskiej zaś lekcja [ewolucja memetyczna]; obie lekcje odnoszą się do ewolucji memów, a nie rodzaju/typu ewolucji (resp. sposób zachodzenia zmian). Philip Pomper w książce The Return of Science: Evolution, History, and Theory (Pomper, Shaw 2002) w rozdziale ósmym zatytułowanym Darwinizing History: The Evolution of Power in Russia (146-188), twierdzi, że ewolucję memów należy tłumaczyć przez analogię do ewolucji genów (replikacja memów jest analogiczna do replikacji genów), różnice zaś dotyczą czasu, by możliwe było aktualne postrzeganie rezultatu.

${ }^{43}$ M. Biedrzycki, Genetyka kultury, Warszawa 1998. „[...] memetycy zakładają, że podmiotem ewolucji kulturowej są różniące się od genów replikatory kulturowe, nazwane przez Richarda Dawkinsa memami. Człowiek miałby być wehikułem dla tych rezydujących w umyśle replikatorów w podobny sposób, w jaki jest wehikułem dla swoich genów. [...] Postuluje się, że memy „rozmnażają się” poprzez wymianę informacji między osobnikami, w wyniku czego w ich mózgach powstają nowe, trwałe struktury, będące materialnym nośnikiem replikatorów kulturowych". Tamże, s. 9. 
Tabela 1: Porównanie oryginału z przekładem Hoffmana - szerszy kontekst.

\begin{tabular}{|c|c|}
\hline The Blind Watchmaker 1986 & Ślepy zegarmistrz 1994 \\
\hline $\begin{array}{l}\text { Brains evolved the capacity to communicate } \\
\text { with other brains by means of language } \\
\text { and cultural traditions. But the new } \\
\text { milieu of cultural tradition opens up new } \\
\text { possibilities for selfreplicating entities. } \\
\text { The new replicators are not DNA and they } \\
\text { are not clay crystals. They are patterns of } \\
\text { information that can thrive only in brains } \\
\text { or the artificially manufactured products of } \\
\text { brains - books, computers, and so on. But, } \\
\text { given that brains, books and computers } \\
\text { exist, these new replicators, which I called } \\
\text { memes to distinguish them from genes, can } \\
\text { propagate themselves from brain to brain, } \\
\text { from brain to book, from book to brain, } \\
\text { from brain to computer, from computer } \\
\text { to computer. As they propagate they can } \\
\text { change - mutate. And perhaps 'mutant' } \\
\text { memes can exert the kinds of influence } \\
\text { that I am here calling 'replicator power'. } \\
\text { Remember that this means any kind of } \\
\text { influence affecting their own likelihood } \\
\text { of being propagated. Evolution under the } \\
\text { influence of the new replicators - memic } \\
\text { evolution - is in its infancy. } \\
\text { (Dawkins 1986, 158) }\end{array}$ & $\begin{array}{l}\text { Mózgi uzyskały w drodze ewolucji zdolność } \\
\text { do komunikowania się z innymi mózgami } \\
\text { za pomocą języka i tradycji kulturowej. } \\
\text { Ale to nowe śodowisko kultury otwiera } \\
\text { nowe możliwości dla samoodtwarzających } \\
\text { się obiektów. Te nowe replikatory nie są } \\
\text { ani cząsteczkami DNA, ani kryształami } \\
\text { minerałów ilastych. Są zbiorami informacji, } \\
\text { które mogą funkcjonować jedynie w móz- } \\
\text { gach lub w sztucznych wytworach mózgów } \\
\text { - to znaczy, w książkach, komputerach } \\
\text { i tak dalej. Skoro jednak istnieją mózgi, } \\
\text { książki i komputery, owe nowe replikatory } \\
\text { - które nazwałem, dla odróżnienia od } \\
\text { genów, „memami” - mogą się przenosić } \\
\text { z mózgu do mózgu, z mózgu do } \\
\text { książki, z książki do mózgu, z mózgu do } \\
\text { komputera, z komputera do komputera. } \\
\text { A przenosząc się mogą ulegaćzmianom, czyli } \\
\text { mutacjom. I możliwe, że takie zmutowane } \\
\text { memy mogą mieć tę własność, którą } \\
\text { określam tu mianem „potęgi replikatora”. } \\
\text { Oznacza ona dowolny rodzaj oddziaływania } \\
\text { wpływającego na prawdopodobieństwo, że } \\
\text { replikator ulegnie powieleniu. Ewolucja } \\
\text { pod wpływem tych nowych replikatorów } \\
\text { - czyli ewolucja memetyczna - dopiero się } \\
\text { rozpoczyna. }\end{array}$ \\
\hline
\end{tabular}

Rejestracja formalna (tj. słownikowa) jednostki mem przypada na rok 2001. Najprawdopodobniej pierwszym słownikiem języka polskiego rejestrującym tę jednostkę jest Wielki stownik ortograficzno-fleksyjny pod red. Jerzego Podrackiego wydany w roku 2001; następna była Encyklopedia powszechna PWN, wersja $1.0 \mathrm{z}$ roku 2005, rejestrując lekcję [mem] i [memetyka], podając definicję tych jednostek, co przedstawia tabela 2.

Źródła nieformalne, takie jak Wikipedia (edycja polska) rejestrują lekcję [mem] prawdopodobnie ok. roku 2006; zaś lekcję [memetyka] prawdopodobnie ok. roku $2004^{44}$. Alternatywne słowniki języka polskiego odnotowują zaś, że jednostka $[\mathrm{mem}]$ jest terminem socjobiologii, a nie memetyki ${ }^{45}$.

${ }^{44}$ Data ustalona na podstawie historii hasła [stan na dzień: 14.05.2015].

45 Źródło: http://sjp.pl/mem [dostęp: 14.05.2015]. 
Tabela 2: Encyklopedia powszechna PWN wersja 1.0 (PWN 2005).

\begin{tabular}{|c|c|}
\hline Encyklopedia powszechna PWN wersja 1.0 rok 2005 & Komentarz \\
\hline $\begin{array}{l}\text { Mem, dźwiękowa lub/i obrazowa jednostka informacji } \\
\text { intelektualnej lub kulturowej, przechowywana w pamięci } \\
\text { człowieka i na dowolnych nośnikach (np. w książce, na płycie } \\
\mathrm{CD} \text { ), przekazywana i odbierana świadomie lub nieświadomie; } \\
\text { mem składa się z semiotycznego rdzenia (pogr. RB) - informacji } \\
\text { właściwej (memotypu), oraz semantycznej otoczki służącej } \\
\text { pozyskaniu uwagi odbiorcy. Koncepcję memów sformułował } \\
\text { w latach 70. XX w. bryt. genetyk R. Dawkins, wykorzystując } \\
\text { podobieństwo memu do genu, jednak geny człowiek przyjmuje } \\
\text { wyłącznie od rodziców, natomiast memem jest wszystko, co } \\
\text { człowiek przejmuje od kogokolwiek przez naśladownictwo, } \\
\text { kopiując, przechowując, przekazując i upowszechniając } \\
\text { zawarte w memie idee lub wzory zachowania; memy znajdują } \\
\text { szerokie zastosowanie w technikach kształtowania opinii publ. } \\
\text { - w propagandzie, reklamie (np. powtarzanie w reklamie } \\
\text { informacji dotyczących produktu zmniejsza u odbiorcy reklamy } \\
\text { wątpliwości, czy ten produkt jest mu rzeczywiście potrzebny) } \\
\text { oraz komunikacji społ., dydaktyce, kierowaniu zespołami ludzi, } \\
\text { psychoterapii i in. Metoda badania kultury i społeczeństwa na } \\
\text { podstawie koncepcji memów nazywa się memetyką. }\end{array}$ & $\begin{array}{l}\text { Traktowanie memu } \\
\text { w kategoriach } \\
\text { semiotycznych } \\
\text { pociąga za sobą } \\
\text { następujące } \\
\text { konsekwencje: } \\
\text { a) rdzeń semiotyczny } \\
\text { należy rozumieć jako } \\
\text { nośnik informacji } \\
\text { właściwej; zaś } \\
\text { b) semantyczną } \\
\text { otoczkę, jako czynnik, } \\
\text { którego zadaniem } \\
\text { jest wzbudzenie } \\
\text { zainteresowania } \\
\text { u odbiorcy. }\end{array}$ \\
\hline $\begin{array}{l}\text { Memetyka, metoda badania kultury i społeczeństwa na } \\
\text { podstawie koncepcji memów (Suplement); tworzy własny } \\
\text { słownik pojęć, typologii i klasyfikacji, często adaptując } \\
\text { terminologię biol. (wirusologia) lub antropologiczną; np. } \\
\text { m. mówi o memotypie przez analogię do genotypu (pełen } \\
\text { zestaw genów danego osobnika) i socjotypie (fenotyp to } \\
\text { zespół cech fiz. danego osobnika). Mem, podobnie jak gen } \\
\text { podlega kopiowaniu, natomiast społ. przejawem memotypu } \\
\text { (rzeczywistej zawartości informacyjnej memu) jest socjotyp. } \\
\text { Według m. podstawowym czynnikiem transmisji kulturowej } \\
\text { (czyli przekazu kulturowego w czasie) jest dobór memetyczny, } \\
\text { analogiczny do teorii doboru naturalnego stworzonej przez } \\
\text { Ch. R. Darwina. Najbardziej nowatorskie ibardzo kontrowersyjne } \\
\text { stwierdzenia przypisują człowiekowi wyłącznie rolę „żywiciela } \\
\text { i transmitera” memów w procesie „ewolucji memetycznej”, } \\
\text { a takie pojęcia jak np. świadomość lub moralność uznają za } \\
\text { pojęcia powstałe w wyniku rozwoju społ.-historycznego. Rozwój } \\
\text { m. wiąże się z postępami biologii molekularnej, neurobiologii } \\
\text { i socjobiologii oraz badaniami nad sztuczną inteligencją. } \\
\text { Obszarem zastosowania m. jest m.in. komunikacja społ. } \\
\text { oraz techniki kształtowania opinii publicznej (propaganda, } \\
\text { reklama), dydaktyka, kierowanie zespołami ludzi, psychoterapia. } \\
\text { R. Dawkins Samolubny gen, Warszawa 1976; M. Biedrzecki } \\
\text { Genetyka kultury, Warszawa 1998. }\end{array}$ & $\begin{array}{l}\text { W haśle podane } \\
\text { jest niepoprawne } \\
\text { źródło: „R. Dawkins, } \\
\text { Samolubny gen, } \\
\text { Warszawa 1976”. } \\
\text { Pierwsze polskie } \\
\text { wydanie tej książki to } \\
\text { rok 1996; podstawą } \\
\text { przekładu polskiego } \\
\text { jest wydanie The Selfish } \\
\text { Gene z roku } 1989 .\end{array}$ \\
\hline
\end{tabular}




\section{Zakończenie}

Henri Poincaré w pracy La science et l'hypothése (1902) ${ }^{46}$ twierdzi, że formułowanie hipotez oraz definiowanie w pierwszej kolejności polega na uznaniu, jako wartości odniesienia, jakiegoś paradygmatu - konwencji, umowy. Jako przykład badacz podaje: „Stuart Mill twierdzi, że każda definicja zawiera jakiś aksjomat, ponieważ niejawnie definiuje istnienie zdefiniowanego przedmiotu" ${ }^{\prime 7}$. Poincaré w cytowanym fragmencie zauważa, że stanowisko Stuarta Milla jest skrótem myślowym. Istnienie przedmiotu czy zjawiska nie może być potwierdzone przez podanie definicji terminu - potrzeba albo przedmiotu albo epistemicznej zgodny odnośnie do jego hipostazowania. Poincaré do definicji podchodzi sceptycznie traktując je jako pseudodefinicje - posługuje się tu określeniem définitions déguisées, co znaczy definicje zamaskowane, przebrane. Przykładami, na które powołuje się Poincaré są aksjomaty w geometrii (fr. axiomes géométriques):

Les axiomes géométriques ne sont donc ni des jugements esthétiques a priori, ni des faits expérimentaux.

Ce sont des conventions; notre choix, parmi toutes les conventions possibles, est guidé par des faits expérimentaux; mais il reste libre et n'est limité que par la nécessité d'éviter toute contradiction. C'est ainsi que les postulats peuvent rester rigoureusement vrais quand même les lois expérimentales qui ont déterminé leur adoption ne sont qu'approximatives. En d'autres termes, les axiomes de la géométrie (je ne parle pas de ceux de l'arithmétique) ne sont que des définitions déguisées ${ }^{48}$.

Poincaré zauważa, że aksjomaty (pewniki) w geometrii zasadzają się na umowie, konwencji, daleko posuniętej, w celu uniknięcia sprzeczności. Innymi słowy jego zdaniem niesprzeczne racje pozostają prawdziwe na mocy umowy nawet wówczas, gdy nie odnoszą się do danych doświadczalnych (fr. faits expérimentaux) czy danych eksperymentalnych. Tak czy inaczej, elementem niezbędnym nauki jest język oraz terminy specjalistyczne. Ułatwiają one - czy też umożliwiają - komunikację środowiska naukowego. Formułowane w języku narodowym hipotezy badawcze czy hipotezy pomocnicze de facto nie mają narodowości, ich treść jest uniwersalna, niezależna od zaplecza kulturowego, historycznego, politycznego czy ekonomicznego osób je formułujących. Przez wgląd w etymologię terminów specjalistycznych, wgląd w historię zmieniających się znaczeń owych terminów można prześledzić sposób rozumienia zjawisk, odtworzyć kierunek myślenia o określonych zjawiskach oraz uniknąć pułapek logicznych.

\footnotetext{
${ }^{46}$ H. Poincaré, La science et l’hypothése, Paris 1902.

47 Tamże, s. 49. «Stuart Mill a prétendu que toute définition contient un axiome, puisqu'en définissant on affirme implicitement l'existence de l'objet défini» [tłum. moje - R.B.].

48 Tamże, s. 56.
} 


\section{BibLIOGRAFIA}

Bednarek A., O „a więc” - rozważania semantyczne, „Acta Universitatis Nicolai Copernici, Filologia Polska XXXIX. Nauki Humanistyczno-Społeczne”, Toruń 1987, z. 174., s. 3-26.

Biedrzycki M., Genetyka kultury, Warszawa 1998.

Boroch R., Siedem bram memetyki (SBM2). Recepcja Samolubnego genu Richarda Dawkinsa w angielskiej literaturze przedmiotu w latach 1976-1989, Warszawa 2016.

Calvin H. W., The Six Essentials? Minimum Requirements for the Darwinian Bootstrapping of Quality, "Journal of Memetics", 1997, no. 7.

Dawkins R., Replicator selection and the extended phenotype, "Zeitschrift fur Tierpsychologie", 1978, no. 47 (1), s. 61-76.

Dawkins R., Selective Neurone Death as a Possible Memory Mechanism, „Nature” 1971, vol. 229, no. 5280, 118-119.

Dawkins R., The Greatest Show on Earth. The Evidence for Evolution, New York 2009.

Dawkins R., The Selfish Gene, Oxford 1976.

Distin K., The Selfish Meme. A Critical Reassessment, Cambridge 2005.

Encyklopedia powszechna PWN, Warszawa 2005.

Gatheres D., Macromemetics: Towards a Framework for the Re-unification of Philosophy, "Journal of Memetics" 1997, no. 1.

Gunders J., Brown D., The Complete Idiot's Guide to Memes, New York 2010.

Hofstadter D., Metamagical Themas: Questing For the Essence of Mind and Pattern, London 1987, s. 65.

Poincaré H., La science et l'hypothése, Paris 1902.

Pomper P., Shaw D.G., The Return of Science: Evolution, History, and Theory, Lanham Md 2002. Stownik grecko polski, t.1-4, red. Z. Abramowiczówna, Warszawa 1965.

Wężowicz-Ziółkowska D., Moc narrativum. Idee biologii we wspótczesnym dyskursie humanistycznym,

Katowice 2008.

\section{Nota o autorze}

Robert Boroch - autor monografii: Siedem bram memetyki (SBM2). Recepcja Samolubnego genu Richarda Dawkinsa w angielskiej literaturze przedmiotu w latach 1976-1989 (2016), Kultura w systematyce Alfreda L. Kroebera i Clyde'a Kluckhohna (2013), W strone semiotyzacji antropologii literatury (2013). Obecnie doktorant na Wydziale Bezpieczeństwa Narodowego Akademii Sztuki Wojennej w Warszawie.

\section{About the author}

Robert Boroch - author of three monographs: Siedem bram memetyki (SBM2). Recepcja Samolubnego genu Richarda Dawkinsa w angielskiej literaturze przedmiotu w latach 1976-1989 (2016), Kultura w systematyce Alfreda L. Kroebera i Clyde'a Kluckhohna (2013), W strone semiotyzacji antropologii literatury (2013). Currently working on PhD dissertation at the National Security Faculty, War Studies University, Warsaw, Poland. 